\title{
CHARACTERISTICS AND IMPORTANCE OF RILL AND GULLY EROSION: A CASE STUDY IN A SMALL CATCHMENT OF A MARGINAL OLIVE GROVE
}

\author{
E.V. TAGUAS ${ }^{1 *}$, E. GUZMÁN ${ }^{1}$, \\ G. GUZMÁN ${ }^{1}$, T. VANWALLEGHEM ${ }^{1}$, J.A. GÓMEZ ${ }^{2}$ \\ ${ }^{1}$ Rural Engineering Department/ Agronomy Department, University of Cordoba, Campus Rabanales, \\ Leonardo Da Vinci building, 14071 Córdoba, Spain. \\ ${ }^{2}$ Institute for Sustainable Agriculture, CSIC, Apartado 4084, 14080 Córdoba, Spain.
}

\begin{abstract}
Measurements of gullies and rills were carried out in an olive orchard microcatchment of 6.1 ha over a 4-year period (2010-2013). No tillage management allowing the development of a spontaneous grass cover was implemented in the study period. Rainfall, runoff and sediment load were measured at the catchment outlet. The objectives of this study were: 1) to quantify erosion by concentrated flow in the catchment by analysis of the geometric and geomorphologic changes of the gullies and rills between July 2010 and July 2013; 2) to evaluate the relative percentage of erosion derived from concentrated runoff to total sediment yield; 3) to explain the dynamics of gully and rill formation based on the hydrological patterns observed during the study period; and 4) to improve the management strategies in the olive grove. Control sections in gullies were established in order to get periodic measurements of width, depth and shape in each campaign. This allowed volume changes in the concentrated flow network to be evaluated over 3 periods (period $1=2010-2011$; period $2=2011-2012$; and period $3=2012-2013$ ). The cumulative precipitation values were $610 \mathrm{~mm}, 219$ $\mathrm{mm}$ and $406 \mathrm{~mm}$ for period 1, 2 and 3, respectively, whereas the sediment ratios of rill erosion to total sediment yield were $44 \%$ and $118 \%$, respectively, with a negative value (as a result of the volume reduction of rills and gullies) in period 3 when the total load was equal to $0.4 \mathrm{tha}^{-1}$. The increased development of the gully network was associated to intense events with a return period of the maximum intensity in 30 minutes greater than 2 years. A high dependency on the sequence of events according to their intensity values could explain the sedimentary budget in the catchment. Most of the events generating runoff in the catchment could contribute to interrill and rill erosion, but only very intense events would allow the runoff to transport sediment to the outlet. In addition to the grass cover, control measures in the gullies would substantially improve the sustainability of the farm. These gullies are important sediment sources, particularly in autumn when there is no vegetation cover and intense rainfall events occur.
\end{abstract}




\section{Características e importancia de la erosión en cárcavas y regueros: un caso de estudio en una microcuenca de olivar}

RESUMEN. En este trabajo se han realizado medidas de cárcavas y regueros en una microcuenca de olivar de 6.1 ha durante un período de 4 años (2010-2013). El manejo en la finca durante el período de estudio ha sido no laboreo permitiendo el desarrollo de la cubierta espontánea en las calles. Además del volumen de regueros y cárcavas, medidas de lluvia, escorrentía y descarga de sedimentos en la salida de la cuenca han sido registradas. Los objetivos de este estudio han sido: 1) la cuantificación de la erosión por flujo concentrado en la cuenca a partir del análisis de los cambios geométricos y geomorfológicos de regueros y cárcavas; 2) evaluar el porcentaje relativo de la erosión por escorrentía concentrada sobre las pérdidas de suelo de la cuenca; 3) explicar la dinámica de la formación de regueros y cárcavas a partir de los patrones hidrológicos observados para mejorar las estrategias de manejo. Una serie de secciones de control fueron establecidas en las cárcavas para tomar medidas periódicas de anchura, profundidad y forma en cada campaña. Así, los cambios de volumen en la red de regueros y cárcavas fueron observados en los tres años intermedios a las medidas (período 1 = 2010-2011; período 2=2011-2012 y período 3=2012-2013). La precipitación acumulada fue de $610 \mathrm{~mm}, 219 \mathrm{~mm}$ and $406 \mathrm{~mm}$ para los períodos 1, 2 y 3 , respectivamente, mientras que los porcentajes de la erosión por flujo concentrado sobre las pérdidas de suelo en la salida de la cuenca fueron 44\%, $118 \%$ y tuvo signo negativo como consecuencia de la reducción del volumen de regueros y cárcavas en el período 3, cuando las pérdidas de suelo fueron de $0.4 \mathrm{tha^{-1 }}$. El incremento del desarrollo de la red de cárcavas podría estar asociado con la generación de eventos con intensidades máximas de precipitación en 30 minutos con períodos de retorno superiores a 2 años. Una alta dependencia en la secuencia de eventos de acuerdo a sus valores de intensidad podría explicar el transporte y redistribución de sedimentos en la cuenca de forma que sólo los eventos intensos permitirían el transporte de sedimentos a la salida. Además de la cubierta espontánea, las medidas de control de las cárcavas y regueros mejorarían o completarían sustancialmente la sostenibilidad en la finca, particularmente en otoño cuando la cubierta está ausente e intensos eventos tienen lugar, siendo la principal fuente de sedimentos la red de regueros y cárcavas.

Key words: concentrated runoff, rills, ephemeral gullies, total sediment load, olive crop.

Palabras clave: escorrentía concentrada, cárcavas efímeras, regueros, descarga total de sedimentos, olivar.

Received 13 November 2014 Accepted 17 February 2015

*Corresponding author: Rural Engineering Department/Agronomy Department, University of Cordoba, Campus Rabanales, Leonardo Da Vinci building, 14071 Córdoba, Spain. E-mail: evtaguas@uco.es 


\section{Introduction}

Knowledge on how soil erosion rates are linked within a catchment to the sediment yield at its outlet is essential, not only for accurately predicting sedimentary budgets, but also for investigating the movement of nutrients, contaminants and associated soil degradation processes and for developing suitable scenarios and efficient management strategies (USDA, 1983; Walling, 1983; Nunez et al., 2009; Vigiak et al., 2012). Sources of sediment must be identified in order to evaluate their contribution, and to plan an adequate program (structure design, treatment) for reducing downstream sediment supply. The relative importance of the sediment sources differs on the different spatial and temporal scales and in different environmental conditions (Lane et al., 1997; Lu et al., 2006). Therefore, an appropriate diagnosis allows to optimize cost and effort, particularly in agricultural areas where economic or management restrictions are frequent.

Land use is determined to some extent by the kind of soil. For instance, agricultural areas are usually located on well-developed soils in order to obtain suitable income levels, as in the case of the current intensive olive plantations. However, traditional olive orchards were cultivated in hilly areas where other Mediterranean crops were scarce or less productive. Both the erosivity derived from the climate and the flow energy associated to the high slopes, and the low soil cover related with water competition lead to a high susceptibility to water erosion and therefore, a major risk of soil and water degradation (Gómez et al., 2014a). Despite the agro-environmental measures applied since the early 2000s to reduce soil erosion, more effort is needed to provide clear management strategies adapted to the geophysical features of the farms as well as its economic restrictions (Taguas et al., 2011a; Castillo et al., 2013). Therefore, the dominance of different erosive processes in the farms such as splash and interrill, rills, ephemeral gullies, gullies or bank failure, have led to a number of control measures and economic investment. Gómez et al. (2011) underlined the lack of specific criteria for protection measures in a complex environmental context such as Andalusia, which can be extrapolated to the rest of the Mediterranean basin where the olive orchard is cultivated. On the other hand, the economic limitations, particularly on commercial farms located in mountainous areas with lower yields and incomes are another aspect illustrating the need for a suitable diagnosis of the main sediment sources and the urgency for developing appropriate control strategies.

The aim of most studies on soil losses in olive orchard land uses has focused on quantifying inter-rill erosion at the plot scale (e.g. Pastor et al., 2001; Francia et al. 2006; Gómez et al., 2004, 2009) or total sediment load at the catchment scale (Taguas et al., 2009; Gómez et al., 2014b). In few studies has the identification of the dominant erosive processes and its dynamic on commercial farms been explored. For instance, Ramos et al. (2008) evaluated by topographical measurements the soil redistribution in a sloping olive tree area in Jaén (Spain). They underlined the fact that the sediment transport was accelerated by tillage with modern heavy machinery. Gómez et al. (2008) mapped and quantified the volume of soil loss associated to rills and ephemeral gullies generated in the year 2008 in an olive orchard microcatchment of 8 ha with a vertic soil in Córdoba (Spain). These authors identified that most of the sediments came from the rills and gullies. Guzmán et al. (2013) compared the erosion rates at the plot scale on one of the 
steepest slopes of the catchment on the same farm. The soil losses were 5.5 times greater on the hillslope than in the plots as a result of the generation of rills and ephemeral gullies, which increased the connectivity in the catchment.

On the other hand, surveys carried out on other agricultural land uses in the Mediterranean area have also justified the description of soil losses resulting from concentrated flow to protect production and sustainability (e.g. De Santisteban et al., 2006; Raclot et al., 2009; Castillo, 2012). In a review by Poesen et al. (2006), the contribution of gully erosion to the total sediment budget was reported to be between $47-83 \%$ for Mediterranean areas.

In Taguas et al. (2011b), the SEDD model (Ferro and Minacapilli, 1995) was calibrated for the period April 2005-April 2008 to evaluate the sediment redistribution in an olive orchard catchment as well as the most erosion-sensitive hillslopes to concentrate soil protection measures. As a continuation, in this work the characteristics and the contribution of the ephemeral gully network to the overall sediment balance were quantified and described over a period of 4 years with considerable variability in precipitation. The particular objectives were 1) to evaluate the geometric and geomorphologic changes of rills and gullies in the study catchment in the period between July 2010 and July 2013, 2) to evaluate the potential contribution of the concentrated runoff erosion to the total sediment yield, 3) to analyze the rain and runoff event patterns observed during the study period to describe the dynamics of gully and rill formation.

\section{Material and Methods}

\subsection{Study site}

The "Puente Genil" catchment $\left(\mathrm{PG} ; 37.4^{\circ} \mathrm{N},-4.8^{\circ} \mathrm{W}\right)$ is located in the southwest of the province of Cordoba, Spain (Fig. 1a). Its drainage area is 6.1 ha and it has been described in different studies (e.g. Taguas et al., 2010, 2011b). Its mean elevation is 239 m.a.s.1., while the mean slope is $15 \%$. It is characterized by the subtype of the Mediterranean climate (Csa; Köppen classification) with an average annual rainfall of around $400 \mathrm{~mm}$. The average temperature in the warmest month is recorded in July $\left(26.5^{\circ} \mathrm{C}\right)$ while the coldest is in January $\left(8.4^{\circ} \mathrm{C}\right)$. The soil type is Cambisol (FAO classification) with a loamy sand texture (14\% clay, $57 \%$ sand and $29 \%$ silt fractions). The areas close to the outlet are old terraces with abundant calcareous coarse materials. The olive trees were planted in 1999, and were spaced $7 \mathrm{~m} \times 7 \mathrm{~m}$ apart. A no-tillage system with spontaneous grass cover growing in winter and spring has been the applied management system since 2005 . The spontaneous vegetation is usually controlled once a year (in March/April/May) using a tractor to mechanically kill the vegetation or by applying herbicide around every tree (or combining both; Table 1). Although tillage operations were not applied and the gullies were not covered on purpose, the traffic might move or disturb the ground surface, mainly during harvesting operations and during the mechanical treatment of the spontaneous grass cover. The impact on the soil surface (and on gullies) derived from the management operations was described in the field during the study period. 
Table 1. Management operations applied during the study period in the catchment.

\begin{tabular}{|c|l|l|l|l|}
\hline Year & Winter & \multicolumn{1}{|c|}{ Spring } & \multicolumn{1}{c|}{ Summer } & \multicolumn{1}{c|}{ Autumn } \\
\hline 2010 & $\begin{array}{l}\text { Herbicidal treatment in } \\
\text { the lanes (glyphosate) }\end{array}$ & $\begin{array}{l}\text { Harvesting- Buggies } \\
\text { and tractor passes }\end{array}$ \\
\hline 2011 & $\begin{array}{l}\text { Tractor passes for } \\
\text { mechanical killing } \\
\text { of weeds; Foliar } \\
\text { fertilisation (N, Mg, Fe) }\end{array}$ & $\begin{array}{l}\text { Harvesting- Buggies } \\
\text { and tractor passes }\end{array}$ \\
\hline 2013 & $\begin{array}{l}\text { Tractor passes for } \\
\text { mechanical killing } \\
\text { of weeds; Treatment } \\
\text { with herbicide in SE } \\
\text { hillslope; }\end{array}$ & $\begin{array}{l}\text { Harvesting- Buggies } \\
\text { and tractor passes }\end{array}$ \\
\hline
\end{tabular}

The catchment outlet is equipped with a gauging station, described in Taguas et al. (2010, 2013), where runoff and sediment loads of the events are measured (Fig. 1a). The relationships intensity-duration-frequency for the catchment were calculated in Taguas (2007). An "event" is defined as a rainfall period separated by a minimum interval of $6 \mathrm{~h}$ without any rainfall in between (Renschler et al. 1999; Domínguez et al., 2007). Precipitation is measured at the outlet of the catchment with one gauge (Hobo Event $7852 \mathrm{M}$ ) with an accuracy of $0.2 \mathrm{~mm}$. The runoff is estimated through a critical flow depth flume (Clemmens et al., 2001) where the water level is measured by an ultrasonic sensor (Milltronics Ultrasonics). Finally, an automatic sampler (ISCO 3700C) is used to take samples of the sediment concentration during the events and to calculate the total sediment load (Taguas et al., 2010).

\subsection{Gully measurements}

The procedure followed in this study is summarized in Fig. 2. Measurements of rills and gullies (Fig. 1b-c) were carried out annually in the catchment from July 2010 to July 2013 (4 years). 147 reference sections were established in the first survey (July 2010), and these have been measured and compared periodically in the rest of the measurement campaigns. Additionally, new measurements were taken to describe new gullies present in the catchment in each of the surveys. The criteria for defining gullies were the geometric characteristics: wider and deeper than $30 \mathrm{~cm}$ or with a cross section greater than $0.929 \mathrm{~cm}^{2}$ (Poesen et al., 1993). In July 2010 and July 2011 (sample dates corresponding to period 1) a tape and a submetric GPS (planimetric precision of $30 \mathrm{~cm}$ ) were used to describe (shape, depth, width; Fig. 3a) and to locate gully sections. In period 1, 153 sections were described while in July 2012 and July 2013, when a GPS of planimetric and altimetric precision of $1 \mathrm{~cm} \pm 2 \mathrm{ppm}$ and $2 \mathrm{~cm} \pm 2 \mathrm{ppm}$ expressed as root square mean error was used, the number of sections 
was 523 and 225, respectively. For the gullies identified in the field, total length, drainage area at their head and volume were also determined. A DEM of $1.5 \mathrm{~m} \times 1.5 \mathrm{~m} \times 0.001 \mathrm{~m}$ (altimetric precision of $0.20 \mathrm{~m}$ ) derived from an ortophotogrammetric flight was considered to determine the drainage areas. Moreover, all the changes observed were described and possible correlations tested. The total volume was calculated as the sum of volumes between two control sections. The soil losses equivalent to the difference of volumes between each year were calculated considering the mean value of bulk density in the first horizon between 0 and $-10 \mathrm{~cm}\left(1.61 \pm 0.11 \mathrm{~g} \mathrm{~cm}^{-3}\right.$; Taguas et al., 2010).

\subsection{Analysis of the hydrological patterns on the gully and rill formation}

Finally, the total sediment yields measured between two surveys were calculated and compared to the equivalent soil losses associated to the volume changes of the gullies. On the annual and event scales, possible patterns explaining the contribution of gullies to the total soil losses in the catchment were studied. At the annual scale, a descriptive analysis of the cumulated values of precipitation, evapotranspiration, runoff and sediment load was also carried out, whereas at the event scale, statistics of the event attributes were calculated: precipitation, duration, erosivity, maximum rainfall intensity in 30 minutes $\left(\mathrm{I}_{30}\right)$, return period of maximum $\mathrm{I}_{30}$, runoff rate, runoff coefficient, peak flow, sediment concentration and total sediment load. In addition, a correlation analysis was carried out to describe possible hydrological patterns associated to the development of gullies in the study catchment.

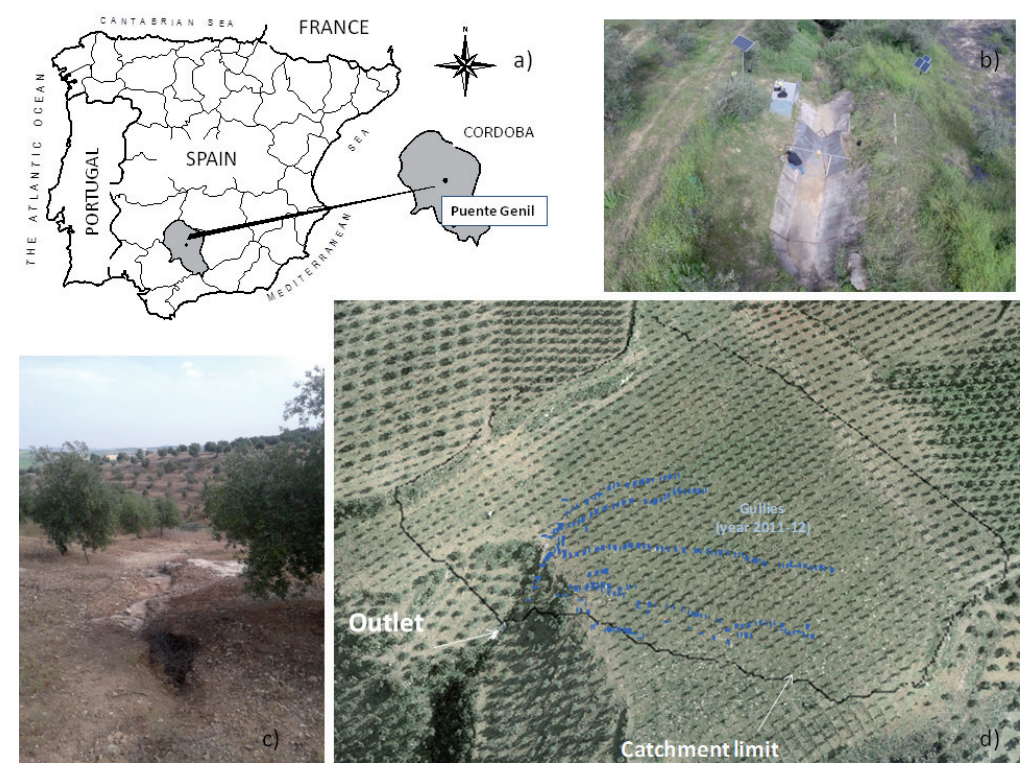

Figure 1. Images of the catchment: a) Location in Spain; b) View of the gauge station with the measuring equipment; c) View of a gully in the catchment; d) Aerial ortophotography with the catchment limits and the gullies identified during the period 2011-2012. 


\begin{abstract}
OBJECTIVE: Analysis of sediment sources from concentrated flow $\rightarrow 147$ cross-sections located by GPS in the gullies to quantify and to interpret the contribution of rills and ephemeral gully network to sediment loads of an olive orchard catchment (commercial farm).
\end{abstract}

MEASUREMENTS

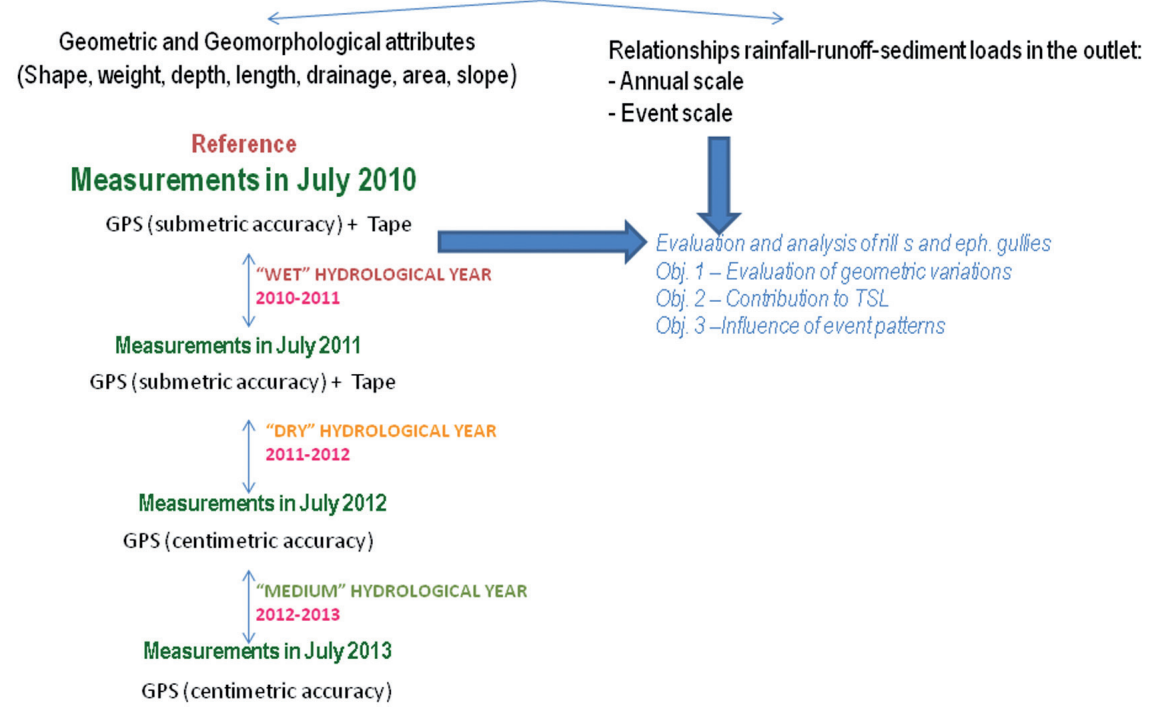

Figure 2. Summary of the procedure.

\title{
3. Results
}

\subsection{Geometric and geomorphologic attributes of gullies}

In the year 2010, 14 gullies, equivalent to a volume of $33.1 \mathrm{~m}^{3}$, were described (Fig 3a, Tables 2 and 3). The mean values of width and depth of gullies were $44.0 \mathrm{~cm}$ and $5.2 \mathrm{~cm}$, respectively, while the total length was equal to $75.0 \mathrm{~m}$. During period 1 (July 2010-July 2011), an accumulated precipitation of $610 \mathrm{~mm}$ was recorded. This is almost 50\% higher than the long-term average annual precipitation and resulted in a notable growth in the gully and rill network (Fig. 3b). New links were observed between previously disconnected rills and gullies: $\mathrm{A}$ and $\mathrm{C}, \mathrm{D}$ and $\mathrm{F}$ and $\mathrm{M}$ and $\mathrm{N}$ (Fig. $3 \mathrm{~b}$ and Table 3). The average widths and depths increased $(51.2 \mathrm{~cm}$ and $5.9 \mathrm{~cm}$, respectively) as well as the total length and volume (79.8 $\mathrm{m}$ and $45.9 \mathrm{~m}^{3}$, respectively). Although only 219 $\mathrm{mm}$ of rainfall was measured in the period 2 (Fig. 4a), much lower than the average, a small, new gully $\mathrm{O}$ was identified. In addition, gullies $\mathrm{A}$ and $\mathrm{C}$ were fully linked, while the small gullies B and $\mathrm{H}$ were filled and subsequently removed. The total volume was greater than the previous years $\left(55.8 \mathrm{~m}^{3}\right.$; Table 2$)$ while the total length was shorter $(977$ $\mathrm{m})$ due to the filling-in of these two gullies. 
Table 2. Summary of the gullies and rills measured in each campaign: number, total volume and length and equivalent soil losses corresponding to the measured volume.

\begin{tabular}{|l|c|c|c|c|}
\hline & July 2010 & July 2011 & July 2012 & July 2013 \\
\hline Number & 14 & 13 & 12 & 9 \\
\hline Total volume $\left(\mathrm{m}^{3}\right)$ & 33.1 & 45.9 & 55.8 & 33.8 \\
\hline Total length $(\mathrm{m})$ & 1049.2 & 1037.6 & 977.0 & 787.3 \\
\hline Equivalent soil losses $(\mathrm{t})$ & 53.0 & 73.4 & 89.3 & 54.1 \\
\hline
\end{tabular}
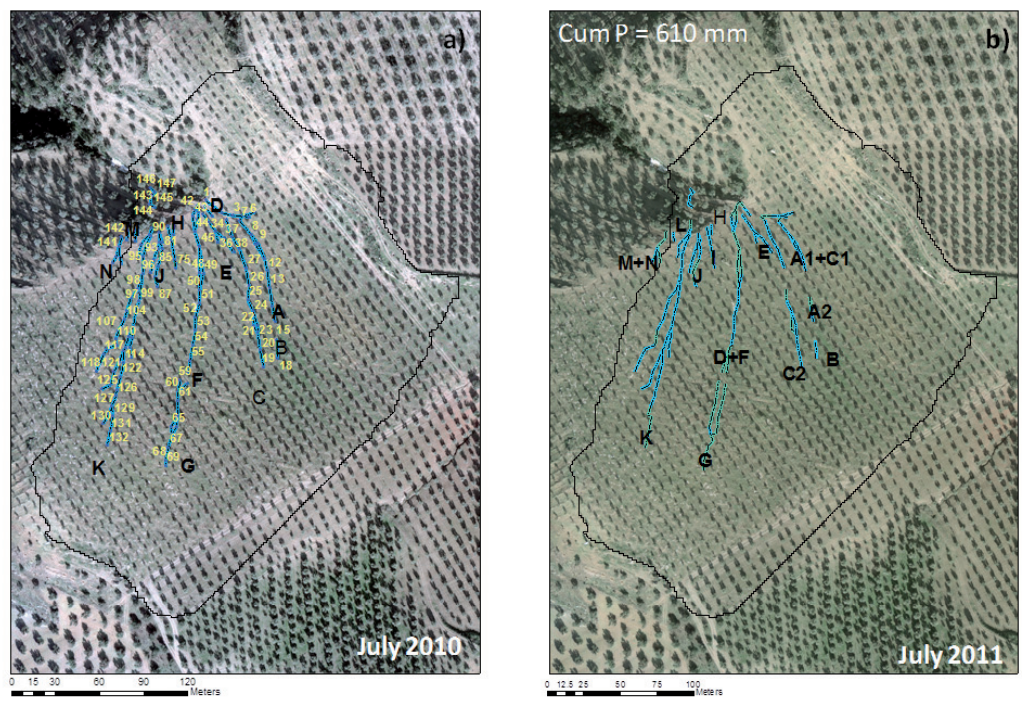

Figure 3. Rills and gullies identified in the catchment in the different measurement campaigns: a) Reference -July 2010; b) July 2011 (Cum P=cumulative precipitation between measurement periods; the numbers indicate the code of the sections).

Finally, the precipitation recorded in the last year was $406 \mathrm{~mm}$, which is close to the long-term mean value in the catchment. In this year, the gully and rill network was notably simplified, and gullies H, I, M and $\mathrm{N}$ disappeared from the area close to the outlet. This area has a gentler slope and is usually used by the tractors to cross the field (Fig. 4b, Table 3). However, a small, new gully $\mathrm{P}$ was identified (Table 3). It is worth noting that greater values of average width and depth $(64.1 \mathrm{~cm}$ and $8.4 \mathrm{~cm})$ did not result in a greater total volume $\left(33.8 \mathrm{~m}^{3}\right.$ ) than the previous year (Tables 2 and 3), mainly because of the filling-in of various gullies.

The mean values of the slope, the local slope in the gully heads and the drainage area in the gully heads were equal to $12.2 \%, 15.4 \%$ and $755 \mathrm{~m}^{2}$, respectively. The variations of the mean were explained by the variations in the number of gullies and its location on the hillslope (Table 3). 

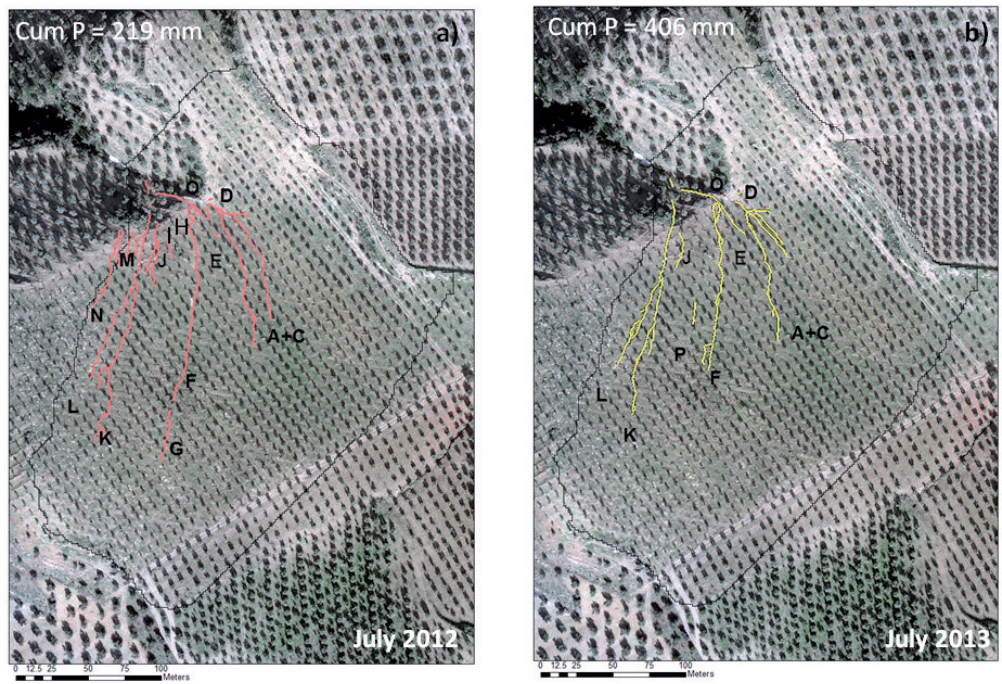

Figure 4. Rills and gullies identified in the catchment in the different measurement campaigns: a) July 2012; b) July 2013 (Cum P = cumulative precipitation between measurement periods).

Table 3. Main attributes and statistics (St. Dv= standard variation; $C V=$ coefficient of variation) of the rills and gullies measured in the study catchment per year.

\begin{tabular}{|c|c|c|c|c|c|c|c|}
\hline Year & Code & $\begin{array}{l}\text { Average } \\
\text { Width } \\
(\mathrm{cm})\end{array}$ & $\begin{array}{c}\text { Average } \\
\text { Depth } \\
(\mathrm{cm})\end{array}$ & $\begin{array}{l}\text { Total } \\
\text { Length } \\
\text { (m) }\end{array}$ & $\begin{array}{c}\text { Drainage } \\
\text { area at } \\
\text { headcut } \\
\left(\mathbf{m}^{2}\right)\end{array}$ & $\begin{array}{c}\text { Mean } \\
\text { slope } \\
(\%)\end{array}$ & $\begin{array}{c}\text { Local } \\
\text { slope at } \\
\text { headcut } \\
(\%)\end{array}$ \\
\hline \multirow{14}{*}{$\begin{array}{c}\text { July } 2010 \\
\text { (Fig. 3a) }\end{array}$} & A & 73.20 & 7.90 & 138.05 & 1690.0 & 7.79 & 11.15 \\
\hline & $\mathrm{B}$ & 54.33 & 1.00 & 12.21 & 90.0 & 11.63 & 11.29 \\
\hline & $\mathrm{C}$ & 56.91 & 7.91 & 119.89 & 360.0 & 10.52 & 11.26 \\
\hline & $\mathrm{D}$ & 43.00 & 4.00 & 8.24 & 2380.0 & 7.16 & 7.16 \\
\hline & $\mathrm{E}$ & 38.33 & 4.00 & 41.25 & 180.0 & 9.87 & 12.42 \\
\hline & $\mathrm{F}$ & 68.74 & 11.84 & 163.71 & 1080.0 & 10.60 & 20.85 \\
\hline & $\mathrm{G}$ & 30.14 & 3.86 & 92.14 & 490.0 & 10.80 & 15.15 \\
\hline & $\mathrm{H}$ & 23.50 & 2.00 & 7.16 & 400.0 & 19.13 & 19.13 \\
\hline & I & 27.25 & 3.00 & 28.75 & 1040.0 & 18.16 & 18.49 \\
\hline & $\mathrm{J}$ & 44.17 & 6.08 & 76.53 & 360.0 & 8.23 & 11.72 \\
\hline & $\mathrm{K}$ & 47.56 & 7.36 & 316.23 & 340.0 & 8.49 & 15.38 \\
\hline & $\mathrm{L}$ & 15.50 & 4.50 & 6.91 & 1040.0 & 23.01 & 23.01 \\
\hline & $\mathrm{M}$ & 40.00 & 6.00 & 6.92 & 110.0 & 19.66 & 19.66 \\
\hline & $\mathrm{N}$ & 53.71 & 3.00 & 31.22 & 20.0 & 11.69 & 15.47 \\
\hline Mean & & 44.02 & 5.18 & 74.94 & 684.3 & 12.62 & 15.15 \\
\hline
\end{tabular}




\begin{tabular}{|c|c|c|c|c|c|c|c|}
\hline Year & Code & $\begin{array}{c}\text { Average } \\
\text { Width } \\
\text { (cm) }\end{array}$ & $\begin{array}{c}\text { Average } \\
\text { Depth } \\
(\mathrm{cm})\end{array}$ & $\begin{array}{c}\text { Total } \\
\text { Length } \\
\text { (m) }\end{array}$ & $\begin{array}{c}\text { Drainage } \\
\text { area at } \\
\text { headcut } \\
\left(\mathbf{m}^{2}\right)\end{array}$ & $\begin{array}{c}\text { Mean } \\
\text { slope } \\
(\%)\end{array}$ & $\begin{array}{c}\text { Local } \\
\text { slope at } \\
\text { headcut } \\
(\%)\end{array}$ \\
\hline St. Dv. & & 16.64 & 2.88 & 87.62 & 686.3 & 5.12 & 4.56 \\
\hline \multirow{13}{*}{$\begin{array}{l}\text { July } 2011 \\
\text { (Fig. 3b) }\end{array}$} & $\mathrm{A} 1+\mathrm{C} 1$ & 57.25 & 9.36 & 129.48 & 2210.0 & 4.79 & 8.77 \\
\hline & A2 & 32.92 & 3.42 & 26.02 & 1690.0 & 7.96 & 11.15 \\
\hline & $\mathrm{C} 2$ & 58.44 & 5.22 & 70.26 & 360.0 & 9.38 & 11.26 \\
\hline & $\mathrm{B}$ & 36.33 & 0.53 & 12.21 & 90.0 & 11.63 & 11.29 \\
\hline & $\mathrm{D}+\mathrm{F}$ & 76.51 & 8.97 & 186.52 & 1610.0 & 9.10 & 18.02 \\
\hline & $\mathrm{E}$ & 46.67 & 4.17 & 41.25 & 60.0 & 9.87 & 12.42 \\
\hline & $\mathrm{G}$ & 45.04 & 2.62 & 102.26 & 480.0 & 10.17 & 14.03 \\
\hline & $\mathrm{H}$ & 47.50 & 4.50 & 7.16 & 400.0 & 19.13 & 19.13 \\
\hline & I & 27.38 & 4.50 & 28.75 & 1040.0 & 18.16 & 18.49 \\
\hline & $\mathrm{J}$ & 59.73 & 6.31 & 76.89 & 360.0 & 8.19 & 11.72 \\
\hline & K & 75.58 & 12.55 & 312.60 & 320.0 & 9.22 & 23.45 \\
\hline & $\mathrm{L}$ & 15.50 & 4.50 & 6.91 & 1040.0 & 23.01 & 23.01 \\
\hline & $\mathrm{M}+\mathrm{N}$ & 86.29 & 10.29 & 37.26 & 20.0 & 12.99 & 15.47 \\
\hline Mean & & 51.16 & 5.92 & 79.81 & 744.6 & 11.82 & 15.25 \\
\hline St. Dv. & & 20.61 & 3.42 & 87.85 & 710.2 & 5.20 & 4.77 \\
\hline July 2012 & $\mathrm{O}$ & 64.39 & 4.90 & 3.58 & 1280.0 & 10.06 & 10.06 \\
\hline \multirow[t]{11}{*}{ (Fig. 4a) } & $\mathrm{A}+\mathrm{C}$ & 60.66 & 7.25 & 227.03 & 370.0 & 5.63 & 8.36 \\
\hline & $\mathrm{D}$ & 70.28 & 4.70 & 9.47 & 2370.0 & 12.33 & 16.38 \\
\hline & $\mathrm{E}$ & 80.64 & 2.57 & 6.01 & 2260.0 & 13.04 & 12.71 \\
\hline & $\mathrm{F}$ & 77.21 & 8.89 & 191.97 & 990.0 & 14.11 & 13.12 \\
\hline & $\mathrm{G}$ & 45.38 & 3.61 & 43.29 & 480.0 & 13.62 & 19.39 \\
\hline & $\mathrm{I}$ & 60.02 & 4.28 & 14.27 & 1040.0 & 17.90 & 18.08 \\
\hline & $\mathrm{J}$ & 70.20 & 7.79 & 73.75 & 350.0 & 9.87 & 21.16 \\
\hline & $\mathrm{K}$ & 161.94 & 12.66 & 300.34 & 150.0 & 2.58 & 14.64 \\
\hline & $\mathrm{L}$ & 54.43 & 6.12 & 19.88 & 5.0 & 19.03 & 22.32 \\
\hline & $\mathrm{M}$ & 74.92 & 8.21 & 24.72 & 1010.0 & 18.77 & 18.41 \\
\hline & $\mathrm{N}$ & 59.99 & 8.17 & 62.69 & 10.0 & 13.41 & 18.66 \\
\hline Mean & & 73.34 & 6.60 & 81.42 & 859.58 & 12.5 & 16.11 \\
\hline St. Dv. & & 29.66 & 2.80 & 100.75 & 802.87 & 5.0 & 4.37 \\
\hline July 2013 & $\mathrm{O}+\mathrm{D}$ & 46.95 & 7.28 & 3.66 & 880.0 & 11.37 & 11.37 \\
\hline \multirow[t]{5}{*}{ (Fig. 4b) } & $\mathrm{A}+\mathrm{C}$ & 73.08 & 8.63 & 222.83 & 160.0 & 5.43 & 14.34 \\
\hline & $\mathrm{E}+\mathrm{F}$ & 84.62 & 9.35 & 229.46 & 1070.0 & 10.11 & 20.21 \\
\hline & $\mathrm{P}$ & 35.20 & 8.09 & 15.25 & 830.0 & 14.39 & 12.74 \\
\hline & $\mathrm{J}$ & 87.00 & 6.59 & 26.10 & 380.0 & 18.25 & 16.19 \\
\hline & $\mathrm{K}$ & 57.72 & 10.49 & 290.03 & 1080.0 & 10.39 & 15.64 \\
\hline
\end{tabular}




\begin{tabular}{|c|c|r|r|r|r|r|r|}
\hline \multirow{2}{*}{ Year } & Code & $\begin{array}{c}\text { Average } \\
\text { Width } \\
(\mathbf{c m})\end{array}$ & $\begin{array}{c}\text { Average } \\
\text { Depth } \\
(\mathbf{c m})\end{array}$ & $\begin{array}{c}\text { Total } \\
\text { Length } \\
(\mathbf{m})\end{array}$ & $\begin{array}{c}\text { Drainage } \\
\text { area at } \\
\text { headcut } \\
\left(\mathbf{m}^{2}\right)\end{array}$ & $\begin{array}{c}\text { Mean } \\
\text { slope } \\
(\mathbf{\%})\end{array}$ & $\begin{array}{c}\text { Local } \\
\text { slope at } \\
\text { headcut } \\
(\mathbf{\%})\end{array}$ \\
\hline Mean & & 64.10 & 8.41 & 131.22 & 733.33 & 11.7 & 15.08 \\
\hline St. Dv. & & 20.96 & 1.41 & 129.64 & 378.93 & 4.3 & 3.09 \\
\hline \multirow{3}{*}{$\begin{array}{c}\text { Global } \\
\text { Statistics }\end{array}$} & Mean & 56.58 & 6.20 & 85.58 & 755.0 & 12.24 & 15.43 \\
\cline { 2 - 8 } & St. Dv. & 24.71 & 2.98 & 95.68 & 677.4 & 4.87 & 4.29 \\
\cline { 2 - 9 } & CV(\%) & 43.7 & 48.1 & 111.8 & 89.7 & 39.8 & 27.80 \\
\cline { 2 - 9 } & Min & 15.50 & 0.53 & 3.58 & 5.0 & 2.58 & 7.16 \\
\cline { 2 - 9 } & Max & 161.94 & 12.66 & 316.23 & 2380.0 & 23.01 & 23.45 \\
\hline
\end{tabular}

No significant correlations were found between the gully attributes, with the exception of the average width with the average depth (Fig. 5a; $\mathrm{r}=0.63, \mathrm{p}<0.05$ ), on the one hand, and with the total length, on the other (Fig. 5b; $r=0.70, p<0.05$ ).

A relatively constant width-depth ratio (WDR) of about 12 was observed for the first three years, while in the last year this lowered to 8. In all cases, these WDR values are much higher than those of ephemeral gullies observed by Casalí et al. (1999) in Navarra or by Poesen et al. (1993) in the Belgian loess belt. This indicates that rill and gully incision in this area are clearly limited by the shallow soil depth and relatively hard sedimentary rock of the $\mathrm{C}$ horizon.
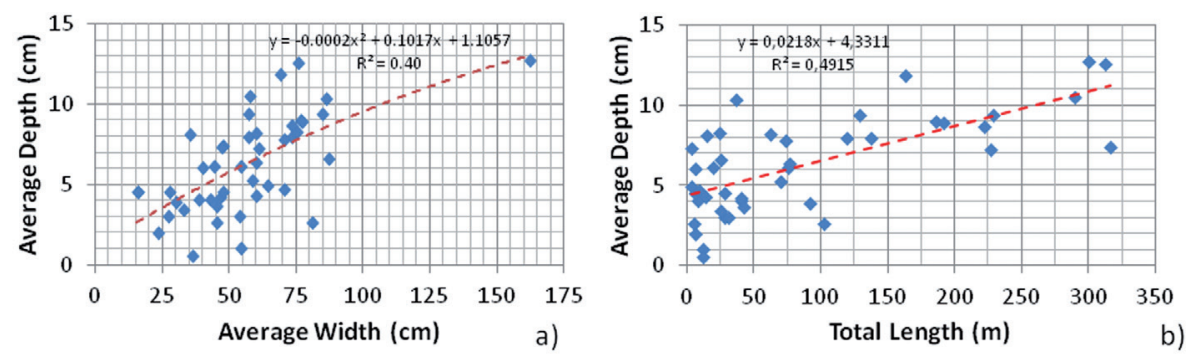

Figure 5. Scatter plots between the average depth and the average width (a) and the total length and the average depth corresponding to the gullies and rills identified in the catchment. (All the study periods and attributes of table 2 were considered).

\subsection{Analysis of the hydrological patterns on the gully and rill formation}

Table 4 shows how in period 1 (July 2010-July 2011), the maximum values of precipitation $(610 \mathrm{~mm})$ and erosivity $\left(992 \mathrm{MJ} \mathrm{mm} \mathrm{ha}^{-1} \mathrm{~h}^{-1}\right)$ resulted in the maximum runoff coefficient $(10 \%)$ and total sediment load $\left(7.8 \mathrm{t} \mathrm{ha}^{-1}\right)$ of the period studied. In contrast, period 2 (July-2011-July 2012) with the minimum values of precipitation and erosivity (219 $\mathrm{mm}$ and $271 \mathrm{MJ} \mathrm{mm} \mathrm{ha}^{-1} \mathrm{~h}^{-1}$, respectively) did not correspond to the 
smallest runoff coefficient and soil losses (7\% and $\left.2.2 \mathrm{t} \mathrm{ha}^{-1}\right)$, which were observed in period 3 (July 2012-July 2013), with an annual precipitation close to the mean value in the catchment. It is worth noting that the contribution of sediments from rills and gullies to the sediment yield in the catchment could not be calculated because the origin of the sediment in the outlet is not known. Thus, only the volume and the fractions of sediment volume from rills and gullies to annual sediment yield are shown in table 4 The difference between gully and rill volumes was equivalent to $44 \%$ of the total sediment load in period $1,118 \%$ in period 2 and to a negative value in period 3 , as a result of the removal of gullies. This shows that the sediment budget in this relatively small catchment is complex and highly dynamic over time. During period 2 , sediment production due to rills and gullies within the catchment was much higher than sediment yield (118\%), which points to the fact that an important deposition took place before reaching the catchment outlet. The actual deposition should be even higher if sediment production due to interrill erosion or bank failure in the stream, which were not measured in this study, was taken into account. Finally, during the last period, the concentrated flow network did not contribute to the overall sediment yield as no net erosion took place here.

Table 4. Annual values of rainfall, evapotranspiration (ETP), erosivity, runoff, runoff coefficient (Runoff/Precipitation x 100), total sediment yield (TSY), soil losses equivalent to the differences of volume in subsequent years from rill and gullies $(S C F)$ and contribution of gully and rill erosion to total sediment yield (SCF/TSL x 100), corresponding to the periods July 2010-July 2011 (Period 1), July 2011-July 2012 (Period 2), July 2012-July 2013 (Period 3).

\begin{tabular}{|l|r|r|r|}
\hline \multicolumn{1}{|c|}{ Measurements } & Period 1 & Period 2 & Period 3 \\
\hline Cum. Rainfall depth $(\mathrm{mm})$ & 609.5 & 218.5 & 406.2 \\
\hline Cum. ETP $(\mathrm{mm})$ & 1394.1 & 1424.5 & 1266.9 \\
\hline Cum. Erosivity $\left(\mathrm{MJ} \mathrm{mm} \mathrm{ha}^{-1} \mathrm{~h}^{-1}\right)$ & 991.9 & 271.4 & 529.9 \\
\hline Cum. Runoff $(\mathrm{mm})$ & 60.1 & 16.1 & 10.9 \\
\hline Runoff coefficient $(\%)$ & 9.9 & 7.4 & 2.7 \\
\hline Total Sediment Yield (outlet, $\left.\mathrm{t} \mathrm{ha}^{-1}\right)$ & 7.8 & 2.2 & 0.4 \\
\hline Sediment Concentrated Flow $\left(\mathrm{t} \mathrm{ha}^{-1}\right)$ & 3.4 & 2.6 & -5.8 \\
\hline Fraction of rill and gully erosion on TSY $(\%)$ & 44 & 118 & - \\
\hline
\end{tabular}

The temporal distribution of the events and their features, shown in Table 5, helps to understand this complex dynamics. For instance, it is remarkable to note how in period 1 only two events that occurred during the fall caused $89 \%$ of the total sediment yield. The most relevant properties of these events were the maximum rainfall intensity, whose return periods were greater than 2 years. Despite the fact that period 2 was notably dry, a unique event occurring on 2 September 2011, with a return period of 4.5 years, caused $76 \%$ of the total sediment load. Finally, no intense events were observed for period 3, as it is shown by the return periods/frequency of the maximum rainfall intensity, which were lesser than 1 year (Table 5). 


\begin{tabular}{|c|c|c|c|c|c|c|c|c|c|c|c|c|c|c|c|c|c|c|}
\hline 岕 & $\begin{array}{l}\infty \\
\ddot{j} \\
\dot{\sim}\end{array}$ & $\stackrel{q}{f}$ & $\begin{array}{l}0 \\
\dot{n}\end{array}$ & $\tilde{a}$ & $\because$ & $\begin{array}{l}\dot{b} \\
\dot{J}\end{array}$ & $\tilde{o}$ & $*$ & $\stackrel{+}{0}$ & $\hat{n}$ & $\stackrel{+}{-}$ & $*$ & $\stackrel{\sim}{n}$ & $\stackrel{\circ}{\circ}$ & $\stackrel{\infty}{\sim}$ & $\underset{\infty}{\stackrel{0}{0}}$ & $\begin{array}{l}m \\
\dot{d}\end{array}$ & $\tilde{0}$ \\
\hline 氖 & 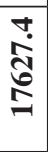 & $\begin{array}{l}n \\
\stackrel{n}{2}\end{array}$ & $\begin{array}{l}0 \\
\dot{0} \\
\infty\end{array}$ & 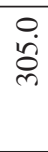 & ?ִ & 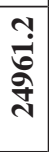 & $\stackrel{n}{n}$ & $\stackrel{\circ}{\circ}$ & @̊. & $\frac{a}{a}$ & $\vec{\infty}$ & $*$ & $\begin{array}{l}0 \\
\ddot{y} \\
\dot{I}\end{array}$ & $\begin{array}{l}\circ \\
\dot{0} \\
\stackrel{\circ}{\infty}\end{array}$ & 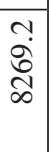 & $\begin{array}{l}\infty \\
\dot{+} \\
\hat{\sigma}\end{array}$ & $\begin{array}{l}n \\
\infty \\
\cdots \\
m\end{array}$ & है. \\
\hline 気 & 卢 & $\begin{array}{l}0 \\
\dot{2}\end{array}$ & $\stackrel{\varphi}{\circ}$ & $\stackrel{n}{\sim}$ & ț. & 我 & $\stackrel{+}{i}$ & $\stackrel{m}{n}$ & $\vec{a}$ & $\stackrel{\circ}{+}$ & $\vec{\jmath}$ & $\stackrel{\sim}{\circ}$ & $\underset{0}{\nabla}$ & $\stackrel{+}{ \pm}$ & $\stackrel{\dot{a}}{\Delta}$ & $\stackrel{\infty}{+}$ & $\stackrel{+}{\dot{r}}$ & $\overrightarrow{0}$ \\
\hline 咅 & $\stackrel{\infty}{\stackrel{\theta}{\Theta}}$ & $\stackrel{?}{+}$ & $\stackrel{\circ}{i}$ & $n$ & $\stackrel{+}{a}$ & $\begin{array}{l}\text { : } \\
\text { : }\end{array}$ & $\stackrel{0}{0}$ & $\stackrel{\sim}{0}$ & $\because$ & $\stackrel{m}{0}$ & $\stackrel{\infty}{0}$ & $\stackrel{n}{0}$ & $\begin{array}{l}\infty \\
0\end{array}$ & $\stackrel{\circ}{\forall}$ & $\stackrel{\infty}{r}$ & : & $\tilde{o}$ & ? \\
\hline 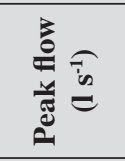 & חִ & $\stackrel{m}{=}$ & $\stackrel{\mathfrak{m}}{\mathrm{r}}$ & $\ddot{a}$ & $\begin{array}{l}n \\
\infty \\
\infty\end{array}$ & พ⿳亠口冋่ & $\stackrel{r}{y}$ & I & $\stackrel{0}{\dot{\gamma}}$ & $\stackrel{\circ}{\dot{d}}$ & $\stackrel{\circ}{\ddot{2}}$ & : & $\stackrel{+}{i}$ & $\stackrel{\sim}{\tilde{y}}$ & $\stackrel{a}{\Xi}$ & స్ & $\overrightarrow{0}$ & ユ \\
\hline 气ี & $\stackrel{m}{\sim}$ & $\stackrel{m}{\sim}$ & $\stackrel{\infty}{a}$ & $\underline{1}$ & $\underset{\infty}{\infty}$ & $\stackrel{\circ}{\circ}$ & $\begin{array}{l}n \\
\infty \\
n\end{array}$ & $\stackrel{n}{\dddot{n}}$ & $\underline{g}$ & $\stackrel{0}{0}$ & $\underset{m}{\stackrel{m}{ }}$ & $\stackrel{\circ}{\circ}$ & in & $\stackrel{?}{I}$ & $\begin{array}{l}0 \\
\ddot{n}\end{array}$ & F & $\ddot{n}$ & 三 \\
\hline 四畐豆 & $\stackrel{ \pm}{ \pm}$ & $\begin{array}{l}n \\
\varrho\end{array}$ & $\begin{array}{l}n \\
\infty \\
a\end{array}$ & $\begin{array}{l}0 \\
\infty \\
\infty\end{array}$ & $\frac{n}{n}$ & तें & ?? & $\stackrel{m}{\sim}$ & $\stackrel{m}{n}$ & $\stackrel{0}{0}$ & $\begin{array}{l}\infty \\
\ddot{n}\end{array}$ & $\begin{array}{l}\infty \\
\stackrel{\sim}{\sigma}\end{array}$ & i. & $\begin{array}{l}n \\
0 \\
0\end{array}$ & $\vec{\infty}$ & $\begin{array}{l}\stackrel{0}{0} \\
\stackrel{\text { సे }}{2}\end{array}$ & $\tilde{0}$ & $\stackrel{m}{\sim}$ \\
\hline 䓃 & $\stackrel{\infty}{\sim}$ & $\overrightarrow{0}$ & $\stackrel{\circ}{0}$ & 0 & $\overrightarrow{0}$ & $\stackrel{m}{i}$ & $\stackrel{0}{0}$ & $\stackrel{\circ}{\circ}$ & $\stackrel{0}{0}$ & $\stackrel{\circ}{\circ}$ & $\stackrel{\circ}{0}$ & $\ddot{0}$ & $\overrightarrow{0}$ & $\stackrel{+}{\circ}$ & $\stackrel{0}{\circ}$ & 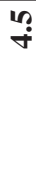 & $\begin{array}{l}0 \\
0\end{array}$ & ن. \\
\hline 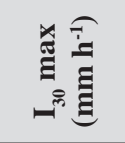 & $\dot{m}$ & 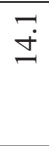 & $\grave{0}$ & $n$ & $\stackrel{+}{ \pm}$ & 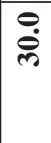 & $\stackrel{0}{\circ}$ & $\underbrace{0}_{0}$ & $\stackrel{1}{\sim}$ & $\begin{array}{l}\infty \\
\infty \\
\infty\end{array}$ & $\ddot{n}$ & ?ִ & $\begin{array}{l}\infty \\
\dot{\Xi}\end{array}$ & $\stackrel{+}{\stackrel{\sim}{\sigma}}$ & $\underset{\infty}{+}$ & लें & $\begin{array}{l}n \\
\infty\end{array}$ & $\begin{array}{l}0 \\
0\end{array}$ \\
\hline 产 & $\begin{array}{l}\infty \\
\stackrel{\sim}{q}\end{array}$ & $\stackrel{\infty}{m}$ & in & $\stackrel{+}{\ddot{d}}$ & aे & ఫें & ণें & $\underset{\infty}{+}$ & ఠo & $\stackrel{\circ}{\circ}$ & $\begin{array}{l}0 \\
\infty \\
\infty \\
\sim\end{array}$ & $\underset{\infty}{+}$ & $\exists$ & $\hat{\text { d }}$ & $\begin{array}{l} \\
\dot{J}\end{array}$ & लें & $\begin{array}{l}\infty \\
\dot{n} \\
\sim\end{array}$ & वे \\
\hline 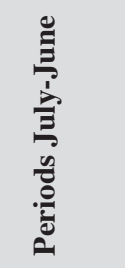 & 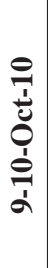 & $\begin{array}{l}0 \\
1 \\
0 \\
0 \\
1 \\
\frac{1}{m} \\
0 \\
0\end{array}$ & $\begin{array}{l}0 \\
1 \\
2 \\
0 \\
z_{1} \\
\stackrel{1}{N} \\
\text { b } \\
\text { r }\end{array}$ & $\begin{array}{l}0 \\
1 \\
z \\
z \\
z \\
1 \\
\text { à }\end{array}$ & 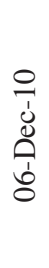 & 重 & 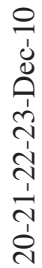 & $\begin{array}{l}0 \\
\frac{1}{0} \\
\frac{1}{n} \\
\frac{1}{m}\end{array}$ & $\begin{array}{l}\bar{J} \\
\dot{d} \\
\text { ấ } \\
\text { à } \\
\infty\end{array}$ & $\begin{array}{l}= \\
\stackrel{1}{\vdots} \\
\stackrel{\Xi}{ \pm} \\
\stackrel{\infty}{d}\end{array}$ & 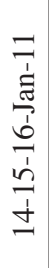 & 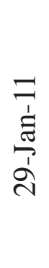 & $\begin{array}{l}= \\
\vdots \\
\vdots \\
\frac{1}{1} \\
0\end{array}$ & $\sum^{\Xi}$ & $\begin{array}{l}\dot{\vec{\nu}} \\
\dot{\vec{n}}\end{array}$ & 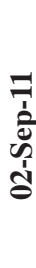 & 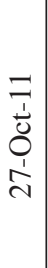 & \\
\hline
\end{tabular}




\begin{tabular}{|c|c|c|c|c|c|c|c|c|c|c|c|c|c|c|}
\hline 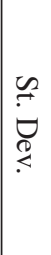 & \begin{tabular}{l}
3 \\
\hdashline \\
\hdashline
\end{tabular} & 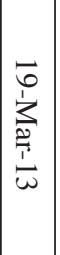 & 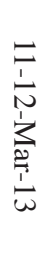 & 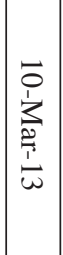 & $\left|\begin{array}{c}\vec{v} \\
1 \\
\infty \\
1 \\
\dot{z} \\
0 \\
2 \\
\vdots \\
\omega \\
\omega\end{array}\right|$ & 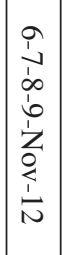 & 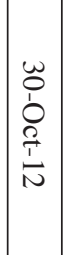 & $\mid \begin{array}{c}N \\
N \\
N \\
\infty \\
1 \\
i n \\
\mathbb{d} \\
\frac{1}{1} \\
\frac{N}{N}\end{array}$ & 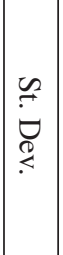 & $\begin{array}{l}3 \\
\mathbb{8} \\
\stackrel{8}{3}\end{array}$ & 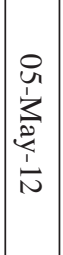 & $\mid \begin{array}{c}n \\
+ \\
+ \\
Z \\
0 \\
\vdots \\
\vdots \\
=\end{array}$ & $\begin{array}{l}w \\
w \\
+ \\
z \\
0 \\
0 \\
\dot{1} \\
\vdots \\
=\end{array}$ & 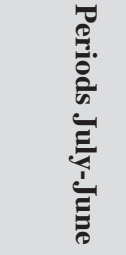 \\
\hline$\ddot{\infty}$ & $\stackrel{\omega}{-}$ & $\stackrel{N}{+}$ & $\begin{array}{l}\tilde{u} \\
\omega \\
\omega\end{array}$ & $\begin{array}{l}\vec{u} \\
0\end{array}$ & $\begin{array}{l}\infty \\
\infty \\
+ \\
\end{array}$ & $\begin{array}{c}\hat{\omega} \\
\dot{0}\end{array}$ & $\begin{array}{l}\overrightarrow{0} \\
\text { i }\end{array}$ & $\begin{array}{l}\text { yo } \\
\text { io }\end{array}$ & $\begin{array}{l}0 \\
\text { iv }\end{array}$ & $\vec{a}$ & $\overrightarrow{\hat{\omega}}$ & ir & $\ddot{a}$ & 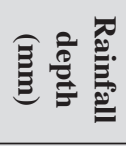 \\
\hline$\stackrel{9}{-}$ & $\Xi$ & $\begin{array}{l}0 \\
\text { iv } \\
\end{array}$ & 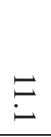 & $\stackrel{\sim}{\sim}$ & $\vec{\perp}$ & $\begin{array}{l}\overrightarrow{0} \\
\dot{\omega}\end{array}$ & $\stackrel{\vec{A}}{+}$ & $\begin{array}{l}\tilde{u} \\
\dot{0} \\
0\end{array}$ & : & $\overline{6}$ & $\stackrel{\sim}{\sim}$ & $\begin{array}{l}0 \\
\text { iv } \\
\end{array}$ & 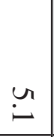 & 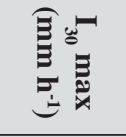 \\
\hline$\stackrel{0}{i}$ & $\stackrel{0}{-}$ & $\stackrel{0}{0}$ & $\stackrel{\circ}{\circ}$ & $\begin{array}{l}0 \\
0\end{array}$ & $\stackrel{0}{0}$ & $\stackrel{\circ}{\circ}$ & 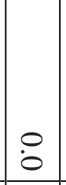 & : & $\dot{\infty}^{\prime}$ & $\stackrel{0}{ }$ & : & : & $\because$ & 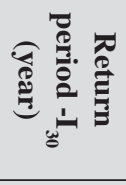 \\
\hline $\begin{array}{l}\infty \\
\infty \\
i\end{array}$ & $\begin{array}{l}\hat{y} \\
\text { io }\end{array}$ & $\begin{array}{l}w \\
\stackrel{w}{\alpha} \\
i\end{array}$ & $\begin{array}{l}N \\
\infty \\
\text { in } \\
\end{array}$ & $\begin{array}{l}\bar{N} \\
0\end{array}$ & $\begin{array}{l}w \\
\mathscr{o} \\
0 \\
0\end{array}$ & $\begin{array}{l}\overrightarrow{+} \\
+\infty\end{array}$ & $\begin{array}{l}\vec{u} \\
0\end{array}$ & $\begin{array}{c}N \\
N \\
\infty \\
0 \\
\end{array}$ & $\begin{array}{l}\overrightarrow{0} \\
6 \\
0\end{array}$ & $\begin{array}{l}\vec{t} \\
0\end{array}$ & $\begin{array}{l}\vec{P} \\
+\end{array}$ & $\stackrel{0}{\circ}$ & $\begin{array}{l}\vec{\omega} \\
\infty\end{array}$ & 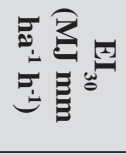 \\
\hline$\stackrel{N}{\sim}$ & $\stackrel{N}{+}$ & $\vec{v}$ & $\stackrel{N}{i}$ & $\vec{a}$ & $\begin{array}{l}\overrightarrow{0} \\
\text { i }\end{array}$ & $\begin{array}{l}w \\
\text { iv }\end{array}$ & $\vec{i}$ & $\vec{v}$ & $\vec{i}$ & $\overline{6}$ & $\vec{a}$ & $\doteqdot$ & $\begin{array}{l}\text { O } \\
\text { in }\end{array}$ & 已气 \\
\hline वे & $\begin{array}{l}1 \\
\infty \\
0\end{array}$ & 至 & $\begin{array}{l}w \\
\infty \\
\omega \\
\omega\end{array}$ & $\dot{\infty}^{\prime}$ & $\begin{array}{l}\tilde{N} \\
\stackrel{\omega}{\omega}\end{array}$ & w & : & \begin{tabular}{|l|}
$\infty$ \\
$\dot{0}$ \\
$\omega$ \\
\end{tabular} & $\frac{\vec{b}}{i \omega}$ & $\stackrel{\varnothing}{\not}$ & in & io & $\stackrel{\vartheta}{\beth}$ & 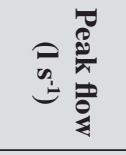 \\
\hline$\dot{a}$ & à & i & $\overrightarrow{+}$ & $\stackrel{0}{0}$ & i & $\omega$ & 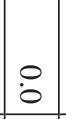 & $\begin{array}{l}\omega \\
\alpha \\
\end{array}$ & iv & $\stackrel{N}{\sim}$ & : & 0 & i & 胥芯 \\
\hline$\dot{0}$ & 90 & $\stackrel{\oplus}{\sim}$ & ur & i & $\stackrel{\oplus}{\sim}$ & 9 & : & $\begin{array}{l}\text { N } \\
\infty \\
\infty\end{array}$ & $\overrightarrow{0}$ & $\begin{array}{l}\infty \\
i \\
\end{array}$ & : & ir & 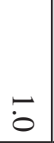 & తి $\stackrel{8}{8}$ \\
\hline $\begin{array}{l}\text { 心 } \\
\text { - } \\
-\end{array}$ & $\begin{array}{l}w \\
\pm \\
i \\
0\end{array}$ & $\begin{array}{l}0 \\
\text { U } \\
\text { in }\end{array}$ & \begin{tabular}{|c|}
$w$ \\
0 \\
0 \\
$\infty$
\end{tabular} & : & $\begin{array}{l}\vec{a} \\
\end{array}$ & 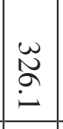 & $\stackrel{0}{0}$ & \begin{tabular}{|l}
$\vec{v}$ \\
$\infty$ \\
$i$ \\
$i$
\end{tabular} & $\begin{array}{l}0 \\
0 \\
+1 \\
0 \\
0\end{array}$ & 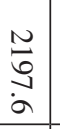 & $\begin{array}{l}0 \\
0\end{array}$ & i & 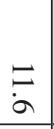 & 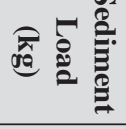 \\
\hline$\omega$ & $\stackrel{N}{\omega}$ & o & $\begin{array}{l}+ \\
0\end{array}$ & $*$ & $\stackrel{0}{i}$ & $\vec{\Phi}$ & $*$ & ur & $\begin{array}{l}\omega \\
\infty \\
\infty\end{array}$ & $\vec{v}$ & : & i & $\bar{i}$ & 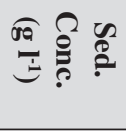 \\
\hline
\end{tabular}


The correlation analysis presented in Table 6 illustrates the importance of the maximum rainfall intensity on the runoff and erosive responses of the catchment. The maximum rainfall intensity in 30 minutes showed the greatest correlation coefficients with the runoff $(0.80, \mathrm{p}<0.05)$, runoff coefficient $(0.80, \mathrm{p}<0.05)$ and sediment load $(0.80$, $\mathrm{p}<0.05$ ). In contrast, the rainfall depth showed very poor correlations (Table 5).

Table 6. Correlation coefficients between the event features for the study period $\left(E_{30}=\right.$ erosivity; $I_{30}=$ maximum intensity in 30 minutes; $I_{10}=$ maximum intensity in 10 minutes).

\begin{tabular}{|c|c|c|c|c|c|}
\hline $\begin{array}{c}\text { Correlation } \\
\text { coefficients }\end{array}$ & Peak flow & Runoff & $\begin{array}{c}\text { Runoff } \\
\text { coeff. }\end{array}$ & $\begin{array}{c}\text { Sediment } \\
\text { Load }\end{array}$ & $\begin{array}{c}\text { Sediment } \\
\text { Concentration }\end{array}$ \\
\hline Rainfall depth & $\mathbf{0 . 4 1}$ & 0.38 & 0.33 & 0.32 & -0.30 \\
\hline $\mathrm{I}_{30}$ max & $\mathbf{0 . 8 9}$ & $\mathbf{0 . 8 0}$ & $\mathbf{0 . 8 0}$ & $\mathbf{0 . 8 0}$ & -0.10 \\
\hline Return period $-\mathrm{I}_{30}$ & $\mathbf{0 . 8 4}$ & $\mathbf{0 . 7 7}$ & $\mathbf{0 . 7 4}$ & $\mathbf{0 . 7 8}$ & -0.08 \\
\hline $\mathrm{EI}_{30}$ & $\mathbf{0 . 8 5}$ & $\mathbf{0 . 7 9}$ & $\mathbf{0 . 7 9}$ & $\mathbf{0 . 7 3}$ & -0.22 \\
\hline Duration & -0.13 & -0.11 & -0.18 & -0.13 & -0.13 \\
\hline
\end{tabular}

Correlations marked in bold are significant at $\mathrm{p}<.05$.

\section{Discussion}

The growth of rill and gully networks in the catchment seemed to be controlled by single events that generate a relatively large runoff volume, which might happen also in dry years. It is worth noting how the ephemeral gully network varied each year, possibly as a result of scour and filling processes. The mechanical impact of the tractor traffic is another factor to mention regarding the variations of gully volumes. However, in our study, there were no appreciable reductions in width associated to the impact of traffic (Fig. 6a). In fact, rill and gullies were not generated over tractor tracks. In Fig. 6 the distribution of widths and depths of the permanent sections are shown for all the measurement campaigns. It is worth noting how in Fig. 6a the widths increased every year, with the exception of the last one, when they remained the same. The greatest depths were observed in the last two years while the first ones (measured in 2010 and 2011, period 1) were shorter and showed very close values (Fig. 6b). As described in table 1, the traffic on the hillslope paths was not intense and therefore did not substantially limit our conclusions. Authors such as Luk et al. (1993) determined, in a semi-arid rangeland plot in Arizona, that for shallow rills, local variations in hydraulic conditions may lead to deposition of sediment derived from upslope. They explained that due to limited runoff and sediment from interrill areas associated to low antecedent soil moisture conditions, part of the sediment was deposited in the tributary rills. In the study catchment, most of the events generating runoff in the catchment contribute to interrill and rill erosion. However, only very intense events would allow the runoff to transport sediment all the way to the outlet. In other cases, there might be intermediate deposition within the network itself. Therefore, there should be a high dependency on the sequence of events according to their intensity values to explain the sediment budget in the catchment. 
In this context, Lu et al. (2006) demonstrated by modeling that interactions between rainfall attributes (intensity, duration, intermittency) were determinant in explaining the spatial variability of sediment delivery. Reaney et al. (2007) also used the Connectivity of Runoff Model to study the impact of rainfall event features on runoff discharge in semi-arid areas. They underlined that long periods of unbroken high intensity (such as a period of 30 minutes for a catchment of 6.1 ha with an approximate concentration time of 10 minutes), resulted in high runoff coefficient values. If the high-intensity rainfall was fragmented, then the runoff would infiltrate in a short distance down slope, which could be associated with filling of the gully network.
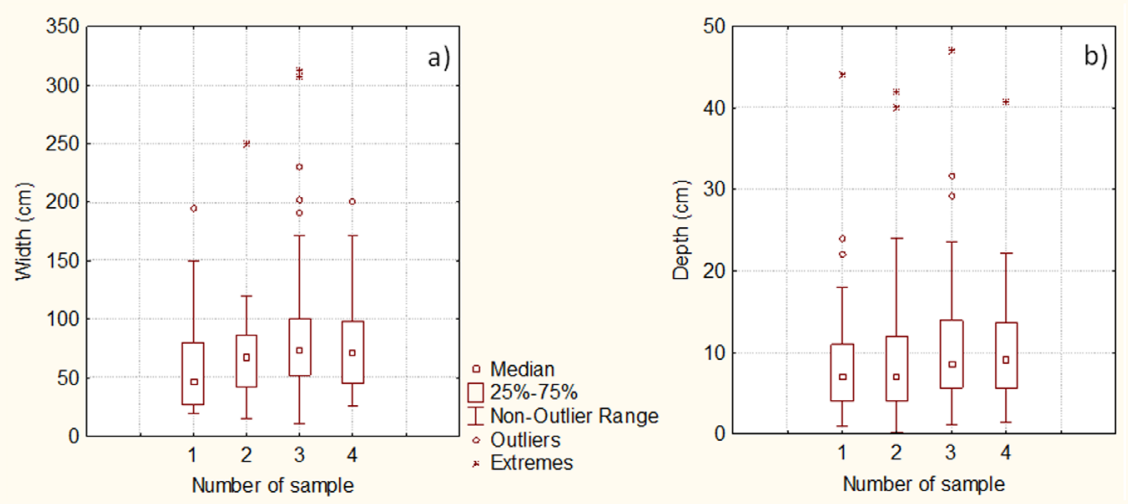

Figure 6. Box-whiskers of widths (a) and depths (b) of the permanent sections in all measurement campaigns.

On the other hand, a unique intense event (2-Sep-11), that belonged to the 2011-2012 dataset (period 2) of a very dry year (with only 5 events generating runoff, see Table 5), caused approximately five times the total sediment load corresponding to the year 20122013 (period 3). These features have been typically observed in semi-arid catchments in numerous studies around the world (Lane et al., 1997; Cammeraat, 2004). Moreover, in this catchment, the high correlation between runoff/peak flow and the maximum rainfall intensities in 30 minutes are clearly associated to the Hortonian flow derived from the high slopes in the Western part of the catchment, where impervious rock outcrops and shallow soils $(<30 \mathrm{~cm})$ are abundant (Taguas et al., 2013).

The influence of spontaneous grass cover and soil moisture at the time of the rainfall event are other factors to take into account with respect to the response patterns of the catchment. In table 4 it can be observed how there are very few events generating runoff in spring, when the cover can present values close to 50\% (Aguilera et al., 2013) and the monthly water deficit (difference between accumulated precipitation and potential evapotranspiration) can be greater than $50 \mathrm{~mm}$ (Aguilera et al., 2013). This leads to consider a dry soil surface in spring. Particularly in the year 2012-2013, despite the fact 
that $31 \%$ of precipitation was concentrated in March, the accumulated runoff was only $2.6 \mathrm{~mm}$, whereas soil losses were also very low (equal to $0.06 \mathrm{t} \mathrm{ha}^{-1}$; Table 5).

Finally, although a complete sediment budget was not established, since interrill erosion and sediment deposition were not measured, the comparison of the rill and gully erosion rates versus the total sediment yield (Table 4) allows us to evaluate the relative importance of the former. For example, for period 1 with 13 events ( 8 of which reached an accumulated rainfall greater than $20 \mathrm{~mm}$ ), rill and gully sediments amounted to approximately $44 \%$ of the total sediment yield. Sediment sources other than gullies (sheet erosion from hillslopes or banks of streams) can be expected to contribute to the total soil losses in the catchment. Luk et al. (1993) found that when flow depth increases in response to the equilibrium runoff associated to wet conditions, net scouring was the dominant process in the rills. The maximum development of the gully and rill network during period 1 could be explained by such process.

In contrast, in a dry period such as 2011-2012, characterized by a precipitation value below the average, but concentrated in few intense events, most sediment must have come from the gullies, because a great quantity of sediment had previously been deposited, which could be transported by these events with enough energy. Unfortunately, there were no measurements to confirm this hypothesis. Table 4 shows how equivalent soil losses from gullies were $118 \%$ of the total sediment load. This low, direct contribution of sediment from the hillslopes can additionally be related to trapping by the spontaneous grass cover and the redistribution favoured by the half-moon shaped hollows dug at the base of the olive trunks (Taguas et al., 2011b). Finally, during the last year 2012-2013, a high deposition and fill is expected as a result of a distribution of events of intensities with a return period of less than 1 year. This agrees with the mean sediment delivery ratio of $4 \%$ determined by the SEDD model (Taguas et al., 2011) for a period of 3 years (2005-2008), with a pattern of 1 or 2 very intense events per year.

\section{Conclusions}

The rill and ephemeral gully network, as well as its geometric features, varied each year, possibly as a result of scour and fill processes. A high dependency on the sequence of events according to their intensity values might explain the sediment budget in the catchment. In fact, a good correlation of runoff and peak flow was observed in the catchment with the maximum rainfall intensities in 30 minutes of the events, related with the Hortonian flow. For storms with limited runoff, most of the sediment would be deposited in the tributary rills, whereas only very intense events would allow the runoff to transport sediment to travel to the outlet.

The growth of the rill and gully network was associated to intense events with a return period of the maximum intensity in 30 minutes greater than 2 years. It was significant how in a year with an accumulated precipitation of only $219 \mathrm{~mm}$, only two events were responsible for a volume change equivalent to $2.6 \mathrm{t} \mathrm{ha}^{-1}$. It is expected that in hydrological years with a similar pattern, the gullies will be one of the main sources of sediments. In the current context of climate change (with less accumulated precipitation 
but more erosive events; Spanish Ministry of Environment, 2005), controlling gullies should be considered an interesting complement to spontaneous grass cover as a tool to maintain sustainability in the field.

\section{Acknowledgements}

This study was supported by Projects AGL2009-12936-C03-01, AGL201240128-C03-01, AGL2012-40128-C03-02 (Spanish Ministry of Science and Innovation), RESEL (Spanish Ministry for Science and Environment) and by FEDER funds. Tom Vanwalleghem acknowledges funding by the Spanish Ministry of Economy and Competitiveness (through the Ramón y Cajal Fellowship RYC-2010-07166).

\section{References}

Aguilera, L., Taguas, E.V., Gimeno, E., Gómez, J.A. 2013. Spatial and temporal variability of grass cover in two olive grove catchments on contrasting soil types. Geophysical Research Abstracts Vol. 15, EGU2013-6364.

Brown, C.B. 1960. Effects of land use and treatment on pollution. In National Conference on Water Pollution, Washington, DC, pp. 209-218.

Cammeraat, E.L.H. 2004. Scale dependent thresholds in hydrological and erosion response of semi-arid catchment in southeast Spain. Agriculture, Ecosystems and Environment 104, 333-342.

Casalí, J., López, J.J, Giráldez, J.V. 1999. Ephemeral gully erosion in southern Navarra (Spain). Catena 36, 65-84.

Castillo C. 2012. Metodología de medida de erosión por cárcavas y modelado de su control mediante diques de retención. Tesis Doctoral. University of Córdoba, Córdoba (Spain), 266 pp.

Castillo, C., Taguas, E.V., Mora-Jordano, J., Gómez, J.A. 2013. Cost analysis of gully restoration in agricultural areas in Andalusia (Spain). European Geosciences Union. Geophysical Research Abstracts Vol. 15, EGU2013-6339.

De Santisteban, L.M., Casalí, J., López, J.J. 2006. Assessing soil erosion rates in cultivated areas of Navarre (Spain). Earth Surface Processes and Landforms 31, 487-506.

Domínguez-Romero, L, Ayuso, J.L., García-Marín, A. 2007. Annual distribution of rainfall erosivity in western Andalusia (southern Spain). Journal of Soil and Water Conservation 62 (6), 390-403.

Ferro, V., Minacapilli, M. 1995. Sediment delivery processes at basin scale. Hydrological Sciences Journal 40, 703-718.

Francia, A., Durán, V., Martínez, A. 2006. Environmental impact from mountainous olive orchards under different soil-management systems (SE Spain). Science of the Total Environment 358, 46-60.

Gómez, J.A., Romero, P., Giráldez, J.V., Fereres, E. 2004. Experimental assessment of runoff and soil erosion in an olive grove on a vertic soil in southern Spain as affected by soil management. Soil Use and Management 20, 426-431.

Gómez, J.A., Taguas, E.V., Vanwalleghem, T., Giráldez, J.V., Sánchez, F., Ayuso, J.L., Lora, A., Mora, J. 2011. Criterios técnicos para el control de las cárcavas, diseño de muros de retención y revegetación de paisajes agrarios. Manual del operador en inversiones no productivas. Junta de Andalucía, Consejería de Agricultura y Pesca, 58 pp. 
Gómez, J.A., Infante-Amate, J., González de Molina, M., Vanwalleghem, T., Taguas, E.V., Lorite, I., 2014a. Olive Cultivation, its Impact on Soil Erosion and its Progression into Yield Impacts in Southern Spain in the Past as a Key to a Future of Increasing Climate Uncertainty. Agriculture 4, 170-198.

Gómez, J.A., Vanwalleghem, T., De Hoces, A., Taguas, E.V. 2014b. Hydrological and erosive response of a small catchment under olivec ultivation in a vertic soil during a five-year period: Implications for sustainability. Agriculture, Ecosystems and Environment 188, 229244.

Guzmán, G., Vanderlinden, K., Giráldez, J.V., Gómez, J.A. 2013. Assessment of spatial variability of water erosion rates in an olive orchard at plot scale using a magnetic iron oxide tracer. Soil Science Society of America Journal 77, 350-361.

Lane, L.J., Hernandez, M., Nichols, M. 1997. Processes controlling sediment yield from watersheds as functions of spatial scale. Environmental Modelling \& Software 12, 355-369.

Lu, H., Moran, C.J., Prosser, I.P. 2006. Modelling sediment delivery ratio over the Murray-Darling Basin. Environmental Modelling and Software 21, 1297-1308.

Luk, S., Abrahams, A.D., Parsons, A.J. 1993. Sediment Sources and Sediment Transport by Rill Flow and Interrill Flow on a Semi-arid Piedmont Slope, Southern Arizona. Catena 20, 93 111.

Nunes, J.P., Seixas, J., Keizer, J.J., Ferreira, A.J.D. 2009. Sensitivity of runoff and soil erosion to climate change in two Mediterranean watersheds. Part I: model parameterization and evaluation. Hydrological Processes 23, 1202-1211.

Pastor, M., Castro, J., Vega, V., Humanes, M.D. 2001. Sistemas de manejo del suelo. In El cultivo del olivo, D. Barranco, R. Fernandez-Escobar, L. Rallo, L. (eds.). Mundi Prensa, Madrid, pp. 198-228.

Poesen, J. 1993. Gully typology and gully control measures in the European loess belt. In Farm Land Erosion in Temperate Plains Environment and Hills, S. Wicherek (ed.). Elsevier, Amsterdam, pp. 221-239.

Poesen, J., Vanwalleghem, T., Gyssels, G., Nachtergaele, J., Verstraeten, G., de Vente, J., 2006. Gully erosion in Europe. In Soil Erosion in Europe, J. Boardman, J. Poesen, J. (eds.), Wiley, pp. 515-536.

Raclot, D., Le Bissonnais, Y., Louchart, X., Andrieux, P., Moussa, R., Voltz, M. 2009. Soil tillage and scale effects on erosion from fields to catchment in a Mediterranean vineyard area. Agriculture, Ecosystems and Environment, 134 201-210.

Ramos, M.I., Feito, F.R., Gil, A.J., Cubillas, J.J. 2008. A study of spatial variability of soil loss with high resolution DEMs: A case study of a sloping olive grove in southern Spain. Geoderma 148, 1-12.

Reaney, S.M., Bracken, L.J., Kirkby, M.J. 2007. Use of the Connectivity of Runoff Model (CRUM) to investigate the influence of storm characteristics on runoff generation and connectivity in semi-arid areas. Hydrological Processes 21, 894-906.

Renschler, C.S., C. Mannaerts, and B. Diekkruger. 1999. Evaluating spatial and temporal variability in soil erosion risk-rainfall erosivity and soil loss ratios in Andalucia, Spain. Catena 34, 209-225.

Spanish Ministery of Environment - MAGRAMA 2005. Principales Conclusiones de la Evaluación Preliminar de los Impactos en España por Efecto del Cambio Climático. Centro de Publicaciones, Secretaría General Técnica Ministerio de Medio Ambiente, Madrid.

Taguas, E.V. 2007. Evaluación de la pérdida de suelo en olivar a escala de microcuenca bajo distintos manejos de suelo. PhD Thesis, University of Cordoba, Cordoba. 
Taguas, E.V., Ayuso, J.L., Peña, A., Yuan, Y., Pérez, R. 2009. Evaluating and modeling the hydrological and erosive behaviour of an olive orchard microcatchment under no-tillage with bare soil in Spain. Earth Surface Processes and Landforms 34, 738-751.

Taguas, E.V., Peña, A., Ayuso, J.L., Pérez, R., Yuan, Y., Giráldez, J.V. 2010. Rainfall variability and hydrological and erosive response of an olive tree microcatchment under no-tillage with a spontaneous grass cover in Spain. Earth Surface Processes and Landforms 35, 750-760.

Taguas, E.V., Giráldez, J.V., Ayuso, J.L., Pérez, R., Castillo, C., Gómez J.A. 2011a. Preliminary assessment and cost analysis of incentives for gully control in agricultural areas of Andalusia (Southern Spain). European Geosciences Union. Geophysical Research Abstracts Vol. 13, EGU2011-4693.

Taguas, E.V., Moral, C., Ayuso, J.L., Pérez, R., Gómez, J.A. 2011b. Modeling the spatial distribution of water erosion within a Spanish olive orchard microcatchment using the SEDD model. Geomorphology 133, 47-56.

Taguas, E.V., Ayuso, J.L., Pérez, R., Giráldez, J.V., Gómez, J.A. 2013. Intra and inter-annual variability of runoff and sediment yield of an olive micro-catchment with soil protection by natural ground cover in Southern Spain. Geoderma 206, 49-62.

USDA-SCS. 1983. National Engineering Handbook: Section 3, Sedimentation. U.S.D.A.-SCS. Washington, pp. 3-1-3-17.

Walling, D.E. 1983. The sediment delivery problem. Journal of Hydrology 65, 209-237. 